\title{
Students' Mathematical Literacy in Solving PISA Problem Using Indonesian Cultural Context
}

\author{
Ratri Murdy Andari ${ }^{*}$, Rini Setianingsih ${ }^{1}$ \\ ${ }^{1}$ Program Studi Pendidikan Matematika, Universitas Negeri Surabaya \\ *Corresponding Author: ratri.17030174017@mhs.unesa.ac.id
}

\begin{tabular}{|c|c|}
\hline ARTICLE INFO & ABSTRACT \\
\hline $\begin{array}{l}\text { Keywords: } \\
\text { Mathematical Literacy, } \\
\text { PISA Problem, } \\
\text { Indonesian Cultural } \\
\text { Context }\end{array}$ & $\begin{array}{l}\text { This study aims to examine students' mathematical literacy in solving PISA } \\
\text { problems using the Indonesian cultural context. This is a descriptive study } \\
\text { with a qualitative approach. As the subject of this study are three 9th grade } \\
\text { students with high, average, and low mathematical abilities. In collecting the } \\
\text { data, the researchers used three instruments, namely, mathematical ability } \\
\text { test, mathematical literacy test, and interview guidelines. The results reveal } \\
\text { that student with high mathematical ability meets all indicators in the process } \\
\text { of formulating, employing, and interpreting. Otherwise, students with } \\
\text { average or low mathematical abilities only meet some indicators in the } \\
\text { process of mathematical literacy. Therefore, it is suggested for the teacher to } \\
\text { provide practice especially for students having average or low mathematical } \\
\text { abilities with literacy problems using contexts that exist in students' life, such } \\
\text { as the Indonesian cultural context. } \\
\text { Published by JRPM (Jurnal Review Pembelajaran Matematika) } \\
\text { This is an open access article under CC BY-SA license } \\
\text { (https://creativecommons.org/licenses/by-sa/4.0/) }\end{array}$ \\
\hline \multicolumn{2}{|c|}{$\begin{array}{l}\text { How to cite: } \\
\text { Andari, R. M. \& Setianingsih, R. (2021). Students' Mathematical Literacy in Solving PISA Problem Using } \\
\text { Indonesian Cultural Context. JRPM (Jurnal Review Pembelajaran Matematika), 6(1), 52-67. }\end{array}$} \\
\hline
\end{tabular}

\section{INTRODUCTION}

The $21^{\text {st }}$ century skills are needed to adapt well in modern society. One of those skills that must be possessed is mathematical literacy (Janah et al., 2019). Anggoro et al.(2019) stated that humans need $21^{\text {st }}$ century skills, and mathematical literacy is an important component to be able to build $21^{\text {st }}$ century skills. It is parallel to what was stated by the Ministry of Education and Culture (2017) that there are several skills needed in the $21^{\text {st }}$ century, including basic literacy, competence, and character.

Mathematical literacy is an individual ability to formulate, apply, and interpret mathematics into various real-life contexts, including the ability to use mathematical concepts, facts, procedures, and tools, to explain, describe, and predict a problem, event, or phenomenon that occurs (OECD, 2017). In harmony with this addition, Ojose (2011) stated that mathematical literacy involves more implementation procedures, which means that it 
needs knowledge and competence to apply in different real-life contexts.

Regulation of the Ministry of Education and Culture Number 64 the Year 2013 regarding learning standards in mathematics, released that the purpose of learning mathematics is that students possess a logical, critical, analytical, careful, thorough, responsible, and not easy to give up in solving problems in mathematics, having a sense of trust in the usefulness of mathematics in daily life, and having an open, objective attitude in daily interactions and activities. If it is compared between the objectives of students' mathematics lessons based on the regulation of the Ministry of Education and Culture with the definition of mathematical literacy, then both have compatibility, meaning that the aim that would be achieved in the regulation of the Ministry of Education and Culture is mathematical literacy.

One indicator that can be used to determine the development of mathematical literacy of Indonesian students can be seen in the OECD Program for International Students Assessment (PISA). PISA monitors the results of student achievement systems in each participating country in terms of literacy (OECD, 2017). PISA aims to assess students at age 15 years, that they have acquired essential knowledge and skills to participate in modern society (Ojose, 2011). In the assessment activities carried out by PISA, Indonesia always participates in it. However, from the reports released by PISA, the results of Indonesian students are not satisfactory (Karmila, 2018).

Assessments of mathematical literacy in PISA have been conducted seven times, namely in 2000, 2003, 2006, 2009, 2012, 2015, and 2018, for the result of the mathematical literacy assessment, the average score of Indonesian students is always below the OECD average (Wulandari \& Azka, 2018). For example, in 2012 the average score of Indonesian students' mathematical literacy is 375, below the OECD average score that is 494. Furthermore, in 2015 Indonesian students had an average score of 386, while the average OECD score is 490. Most recently, in 2018 the average score of Indonesian students is 379 while the average OECD score is 489, around 28\% of Indonesian students reach level 2 or higher in mathematics, while the OECD average is $76 \%$ and about $1 \%$ of Indonesian students are at level 5 or higher in mathematics, while the OECD average is 11\% (OECD, 2018).

However, the low achievement of mathematical literacy is measured using international instruments which the problems in it are global problem life and have not been specifically adapted to Indonesian conditions so that many contexts are unknown to 
Indonesian students (Mahdiansyah \& Rahmawati, 2014). Context is defined as a situation that is described in a problem. The context of mathematical literacy in PISA is divided into four, namely, those related to personal, occupational, societal, and scientific (OECD, 2017).

Based on Mahdiansyah and Rahmawati (2014), the context in literacy is important, because context is related to concepts that students have learned, connects with problems in that context, then looks for solutions that are by the given context. This is in line with Stacey's statement (2011) that context is very important. In general, students are prepared to face the future life that will come, so they need to be introduced to contexts that include aspects of students' life.

Charmila, Zulkardi, and Darmawijoyo (2016) stated that the use of local cultural contexts in solving mathematical literacy problems can help students understand mathematical phenomena from the perspective of student life experiences. Culture is defined as all aspects of human life in society, which are obtained by learning, including feelings, actions, and works (Jalil, 2018). In line with this research, Wahyuni and Pertiwi (2017) explain that culture can be used to solve problems related to students' daily activities. For this reason, the researchers used Indonesian culture in this study, especially Java and Bali cultural contexts.

Related to the results of mathematical literacy, several factors affect the achievement of students' mathematical literacy. Based on the research conducted by Akyüz (2014), the level of student education and student self-confidence affect problem-solving and mathematical literacy. Besides, according to the results of research conducted by Mena, Lukito, and Siswono (2016), Adversity Quotient (AQ) is considered to have a role in the ability to solve contextual problems. However, some of this research do not discuss one of the important factors that contribute to the achievement of mathematics learning outcomes, such as mathematical abilities. This is because the differences in mathematical abilities affect someone in solving mathematics problems (Meiliyah and Setianingsih, 2019).

In line with this opinion, Koshy, Ernest, and Casey (2009) stated that mathematical ability is the ability to master new skills and ideas, as well as to solve new and non-routine mathematical problems. According to the opinion of Krutetskii as quoted in Bartolini (2014), mathematical ability is an ability that consists of the ability to use formal language, operate formal structures, generalize, think logically, solve problems, and remember previously acquired knowledge and concepts. Therefore, mathematical abilities can be used to solve mathematical tasks and mathematical problems effectively. 
There found several studies on mathematical literacy. Lailiyah (2017) showed that female students have good of mathematical literacy skills than male students in geometric problems. Ulfa, Lubab, \& Arrifadah (2017) showed that mathematics learning processes using naive geometry method on the quadratic equation are $22.73 \%$ of students have high mathematical literacy skill, $68.18 \%$ of students have intermediate mathematical literacy and $9.09 \%$ students who have low mathematics literacy. The current study focuses on the research of mathematical literacy in solving the problem with Indonesian cultured context. Based on the discussion above, this research wants to describe how students' mathematical literacy in solving PISA problem using Indonesian cultural context based on students' mathematical abilities.

\section{RESEARCH METHOD}

This study is descriptive with a qualitative approach. The data source of this research is Class IX-A students of Junior High School in Madiun, with several 30 students. This study used three instruments to collect the data, namely, mathematical ability test, mathematical literacy test, and interview guidelines. In collecting the data, 30 students were given a mathematical ability test, to select the research subjects with different categories of mathematical abilities. This research uses the level of mathematical ability as stated in Permendikbud (2014), as can be seen in Table 1 below.

Table 1. Categories of Mathematical Abilities

\begin{tabular}{cc}
\hline Mathematical Abilities & Score \\
\hline High & $80 \leq$ score $\leq 100$ \\
Average & $65 \leq$ score $<80$ \\
Low & $0 \leq$ score $<65$ \\
\hline
\end{tabular}

After being given a mathematical ability test, three students with different mathematical abilities were selected to take a mathematical literacy test. One student with high mathematical ability was given ST code, one student with average mathematical ability was given SS code, and one student with low mathematical ability was given SR code. The reason for choosing ST as the subject because ST had the highest mathematical ability test score. The reason for choosing SS as the subject for average mathematical ability was because the SS score was in the middle of the range of score for the average mathematical ability category in Table 1. While SR was chosen because she had the lowest score of mathematical ability. Besides that, these three subjects were chosen because their gender was a woman. This research was limited to choose a subject who had the same gender. 
After the subjects were selected, they were asked to take a mathematical literacy test, the problems in this mathematical literacy test were adapted from the PISA problem using Indonesian cultural context, especially Java and Bali. The Java and Bali context was designed by the researcher because it is a local cultural context that is close to the subjects' life. In addition, a mathematical literacy test has consisted of three levels, namely levels 4,5 , and 6 . Where each level in mathematical literacy has a different difficulty, the higher the question level, the more complicated and complex the problem is (OECD, 2017). More specifically for problem level 4 is related to the Yogyakarta basket crafts context, for level 5 is related to climbing Mount Lawu in the Karanganyar context, and level 6 is related to Bali Jukungs' boat context. One of the problems in this mathematical literacy test can be seen in Figure 1 below.

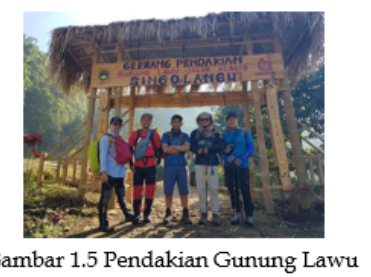

\begin{abstract}
Gunung lawu adalah gunung yang terletak di Karanganyar, Jawa Tengah. Salah satu jalur pendakian gunung Lawu adalah Singolangu, jalur ini dapat ditempuh sekitar 8 kilometer, sehingga untuk naik dan turun ditempuh sekitar 16 kilometer. Pejalan kaki harus kembali pada jam 5 sore karena pintu masuk pendakian tersebut akan ditutup. Danang memperkirakan bahwa ia dapat mendaki gunung dengan kecepatan rata-rata 2 kilometer per jam, dan turun dengan kecepatan dua kali lipat. Kecepatan ini memperhitungkan istirahat makan dan istirahat lainnya. Menggunakan kecepatan perkiraan Danang, berapa waktu maksimal ia bisa mulai mendaki atau naik sehingga ia bisa kembali pada jam 5 sore ? (Berikan prosedur penyelesaian dan jelaskan alasanmu)!
\end{abstract}

Figure 1. The Problem in Mathematical Literacy Test

After the subject took the mathematical literacy test, the subject was interviewed to find indicators of mathematical literacy that are not yet visible on the mathematics literacy test results. The analysis technique used in this research referred to that of Miles, Huberman \& Saldana (2014) which includes data reduction, data presentation, and conclusions. In addition, the indicators that were used in this research were adapted from the three problemsolving processes in mathematical literacy on PISA, as can be seen in Table 2 below.

Table 2. Mathematical Literacy Indicator

\begin{tabular}{ccl}
\hline Mathematical Literacy Process & Code & \multicolumn{1}{c}{ Indicator } \\
\hline Formulate & FO1 & $\begin{array}{l}\text { Identifying the mathematical aspects of the } \\
\text { problem in real context situations and identifying } \\
\text { the variables in the problem }\end{array}$ \\
\cline { 2 - 3 } & FO2 & $\begin{array}{l}\text { Converting problems into suitable mathematical } \\
\text { language into variable form (symbol and model) }\end{array}$ \\
\hline Employ & EM1 & $\begin{array}{l}\text { Design and implement strategies to find } \\
\text { mathematical solutions }\end{array}$ \\
\hline EM2 & $\begin{array}{l}\text { Applying mathematical facts, rules, algorithms, and } \\
\text { structures to find a solution }\end{array}$ \\
\hline Interprete & IN1 & \begin{tabular}{l} 
Interpreting the mathematical result obtained \\
\hline
\end{tabular}
\end{tabular}




\section{RESULT AND DISCUSSION}

\section{Mathematics Literacy Test Results of ST in Solving PISA Problems Using Indonesian Cultural Context}

Based on Figure 2 it appears that in the process of formulating with indicators identifying aspects of mathematics and identifying variables in the problem (FO1), on mathematics literacy problems level 4 that is related to the height of the arrangement of the woven basket which is a handicraft that produced in Yogyakarta, namely in first answer and level 5 that related to the time to start climbing in Lawu Mount through the climbing route in Singolangu, Karanganyar, namely in the second answer, ST did several ways, such as (1) ST wrote important information that is known completely which can be used to find solutions, (2) when interviewed, ST stated that there was no missing important information in the problem, (3) ST could determine what was asked in the question appropriately.

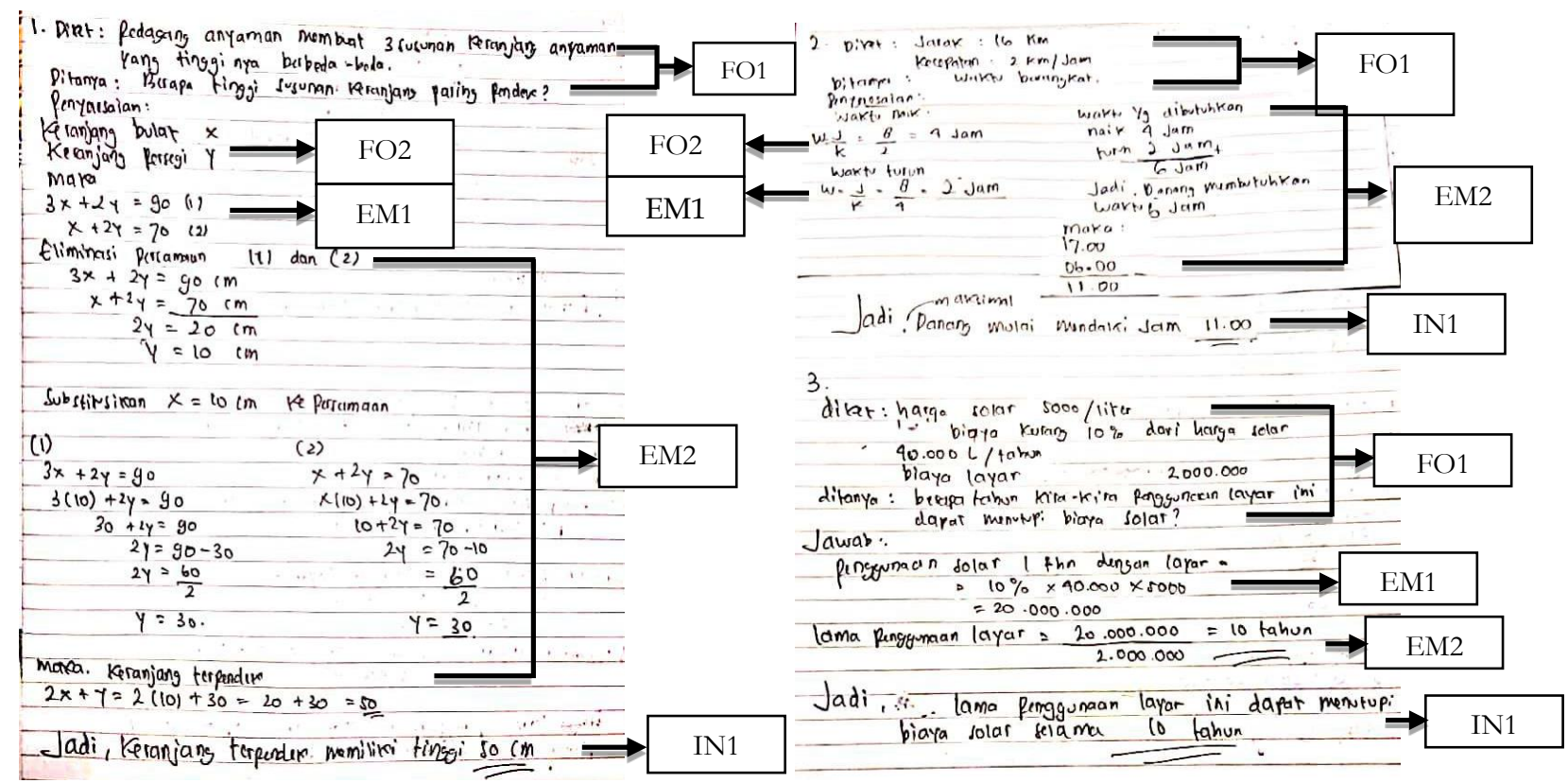

Figure 2. ST Mathematics Literacy Test Answers

While for level 6 mathematical literacy problems that related to the installation of sails on Jukung boat, namely in the third answer, ST wrote important information that was known, but ST was not careful in determining the cost of installing a ship's sail. During the interview, ST stated that the important information that was known in the problem was correct and there was no missing information. For mathematical literacy problems level 6, ST is also able to determine what is being asked in the problem, namely determining the time (in years) needed to use the ship's sails to cover the cost of diesel fuel.

In converting the problem into a suitable mathematical language and variable form 
(symbol and model) (FO2), for level 4 problems, ST takes the height of the cylinder basket with the variable $x$ and the height of the cuboids basket with $y$ and change the arrangement of the basket into the form of a two-variable linear equation. For level 5 problems, ST takes the distance with the variable $j$ and the velocity with the $k$ variable and uses the formula for distance divided by velocity to determine time. While for level 6 questions, ST does not change the problem into a suitable mathematical language in the form of a variable but directly writes it in the form of known values.

In the process of employing indicators to design and implement strategies to find mathematical solutions (EM1) based on the results of answers and interviews, for problems in level 4, ST applies the concept of a two-variable linear equation system, writes down the variables, and then apply arithmetic operations to determine the complete solution. For level 5 problems, ST applies the formula to find time by dividing distance by speed, namely to determine the time to go up the mountain and time to go down the mountain, replace the variables with known values into the formula and then apply the arithmetic operation to find the solution. While, for level 6 problems, ST only multiplies and divides the known values, where S1 should be able to use the concept of a one-variable linear equation.

In applying facts, rules, algorithms, and mathematical structures to find solutions (EM2), at level 4 problems, ST uses elimination and substitution methods to determine the value of $x$ or the height of the cylinder basket and $y$ or the height of the cuboid basket, then ST determines the arrangement of the height of the basket is shortest. For level 5 problems, ST applies the concepts of distance, speed, and time, namely by determining the time to go up the mountain by dividing the distance traveled to go up the mountain with the speed of the climber and determining the time to go down the mountain by dividing the distance traveled to descend with the climber's speed. Then, ST determines the maximum time the climber starts to climb the mountain so he can return on time. Meanwhile, for level 6 problems, ST cannot apply facts, rules, algorithms, and mathematical structures to find solutions correctly.

In the process of interpreting with indicators interpreting the mathematical results obtained (IN1), based on the results of the answers for level 4 and 5, ST carries out several activities such as reading the questions again, checking the completion steps, and explaining the meaning of the results obtained that $50 \mathrm{~cm}$ is the shortest height of the arrangement basket and 11.00 is the maximum time that climbers use to climb the mountain to return on time, namely at $5 \mathrm{pm}$. Meanwhile, for the level 6 problems, ST cannot interpret the 
mathematical results obtained because it cannot design and implement strategies to find mathematical solutions. Further explanation related to the mathematical literacy carried out by ST which is not found in the test results, can be seen in the results of the interview below.

$\mathrm{P} \quad$ : For question number one are you sure there is no missing important information is known in the questions, from the information that you have mentioned?

ST : Yes Miss, in my opinion, I have already mentioned everything

$\mathrm{P} \quad$ : For question number three, what strategy did you do to find a solution?

ST : Actually, I am confused Miss, I just do trial and error and the answer is found, I multiply the price of diesel per liter, the question's fuel consumption per year, and I continue to divide this $10 \%$ by the ship's sail price.

Mathematics Literacy Test Results of SS in Solving PISA Problems Using

\section{Indonesian Cultural Context}

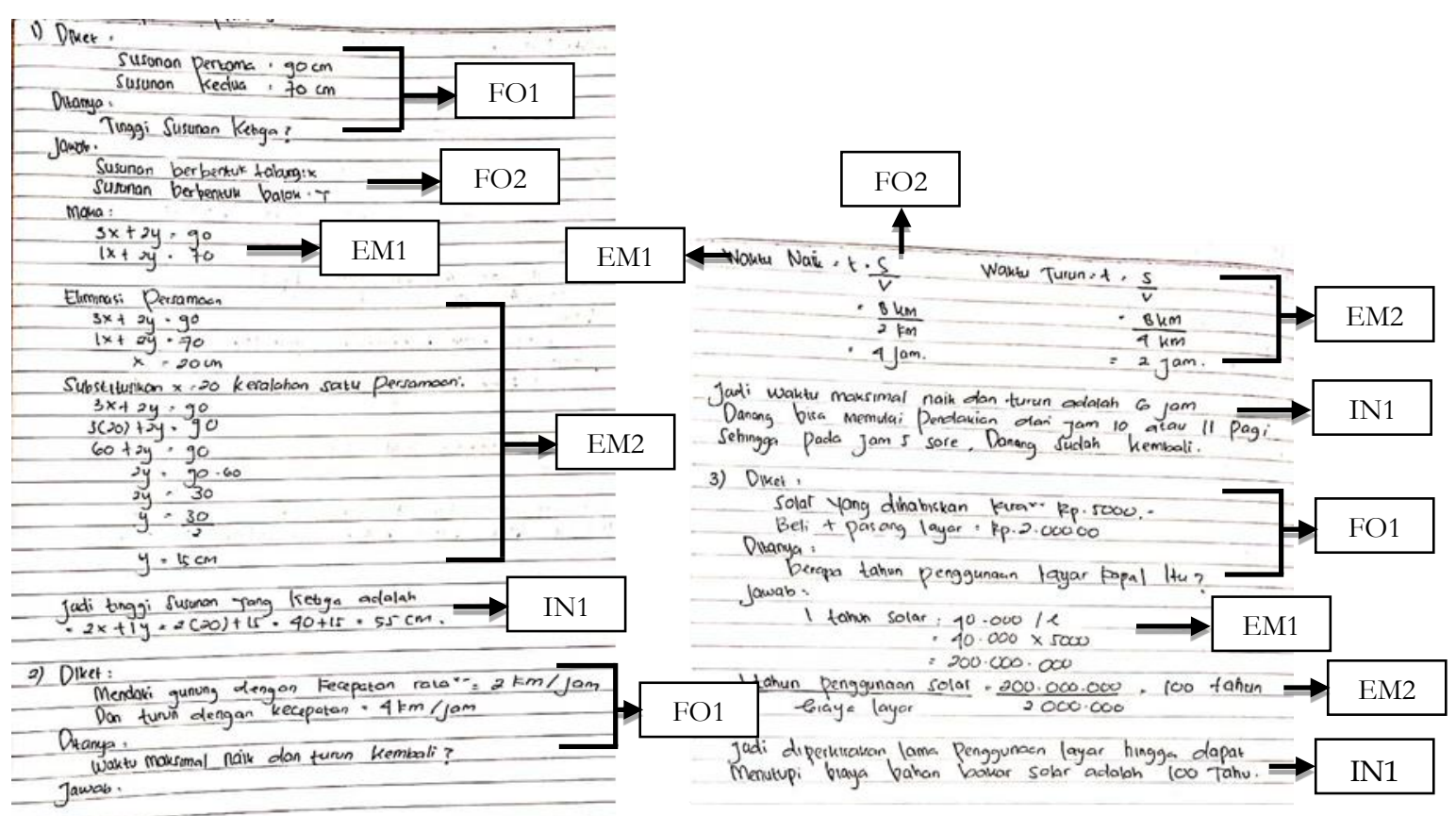

Figure 3. SS Mathematics Literacy Test Answers

In the process of formulating with indicators identifying aspects of mathematics and variables (FO1), on mathematics literacy problems level 4 that is related to the height of the arrangement of the woven basket which is a handicraft that produced in Yogyakarta, and level 5 that related to the time to start climbing in Lawu Mount through the climbing route in Singolangu, Karanganyar, in the first and second answers, SS did several ways, such as (1) SS wrote important information that is known, (2) at the time of the interview SS stated that there was no missing important information that was known in the questions, (3) SS could determine what was being asked. While, for mathematical literacy problems level 6 that related to the installation of sails on Jukung boat, namely in the third answer, SS wrote the information that was known in the incomplete problem, SS could not determine what was 
being asked in the question correctly.

In converting the problem into suitable mathematical language into variable form (a symbol and model) (FO2), for level 4 problems, SS takes the height of the cylinder basket with the variable $x$ and the height of cuboids basket with the variable $y$ then changes the arrangement of each basket into the form of a two-variable linear equation. For level 5 problems, SS changes the problem into a variable form, namely SS calculates the distance with the variable s and the velocity with the variable $v$ and uses it to determine the time $(t)$ that used. While for the level 6 problem, SS does not change the problem into a suitable mathematical language in the form of variables but directly writes it in the form of known values.

In the process of employ with indicators to design and implement strategies to find mathematical solutions (EM1) based on the results of answers and interviews, for problems in level 4, SS applies the concept of a two-variable equation system and performs counting operations to find solutions. For problem level 5, SS applies the relationship between speed, distance, and time to determine the time to go up and down the mountain and then performs arithmetic operations to find a solution. While for level 6 problems, SS cannot apply mathematical formulas and concepts appropriately, SS should be able to use the concept of a one-variable linear equation.

In applying facts, rules, algorithms, and mathematical structures to find solutions (EM2), in level 4 problems, SS applies elimination and substitution to determine the values of $x$ (cylinder basket height) and $y$ (cuboids basket height), but SS is less precise in calculations when SS is interviewed, SS stated that the calculation steps had been carried out correctly, due to a miscalculation, SS could not determine the solution to the solution, namely to determine the exact height of the shortest arrangement. For level 5 questions, SS determines the time by dividing the distance by the speed, then determines the maximum time used to start climbing so that it returns on time, but determining the maximum time used to start climbing the mountain is not quite right. As for the level 6 problem, SS cannot apply facts, rules, algorithms, and mathematical structures to find solutions because it cannot determine the appropriate mathematical concept.

In the process of interpreting with indicators interpreting the mathematical results obtained (IN1), based on the results of the answers to level 4, SS cannot interpret the mathematical results obtained because they cannot apply the algorithm appropriately where there are errors in the completion steps so that they do not can find a solution exactly. For 
the level 5 problem, SS is not correct in interpreting the mathematical results obtained because the solution is the maximum time to start climbing, which is 10.00 or 11.00 , it should be the maximum time used, which is the time that the climber should climb the mountain at 11.00. As for the level 6 problems, SS could not apply the design to find the right answer. Further explanation related to the mathematical literacy carried out by SS which is not found in the test results, can be seen in the results of the interview below.

$\mathrm{P} \quad$ : From the completion steps that you are working on number one, are you sure the calculation you did is correct?

ST : I'm sure Miss

$\mathrm{P} \quad$ : For question number three, what strategy did you do to find a solution?

ST : I don't know Miss, I don't understand the question for number three, I just multiply the amount of diesel per year with the price of diesel per liter then I divided it by the cost of installing the ship's sail, then for this $10 \%$ I was confused where to put it so I didn't include it in the calculation

\section{Mathematics Literacy Test Results of SR in Solving PISA Problems Using Indonesian Cultural Context}

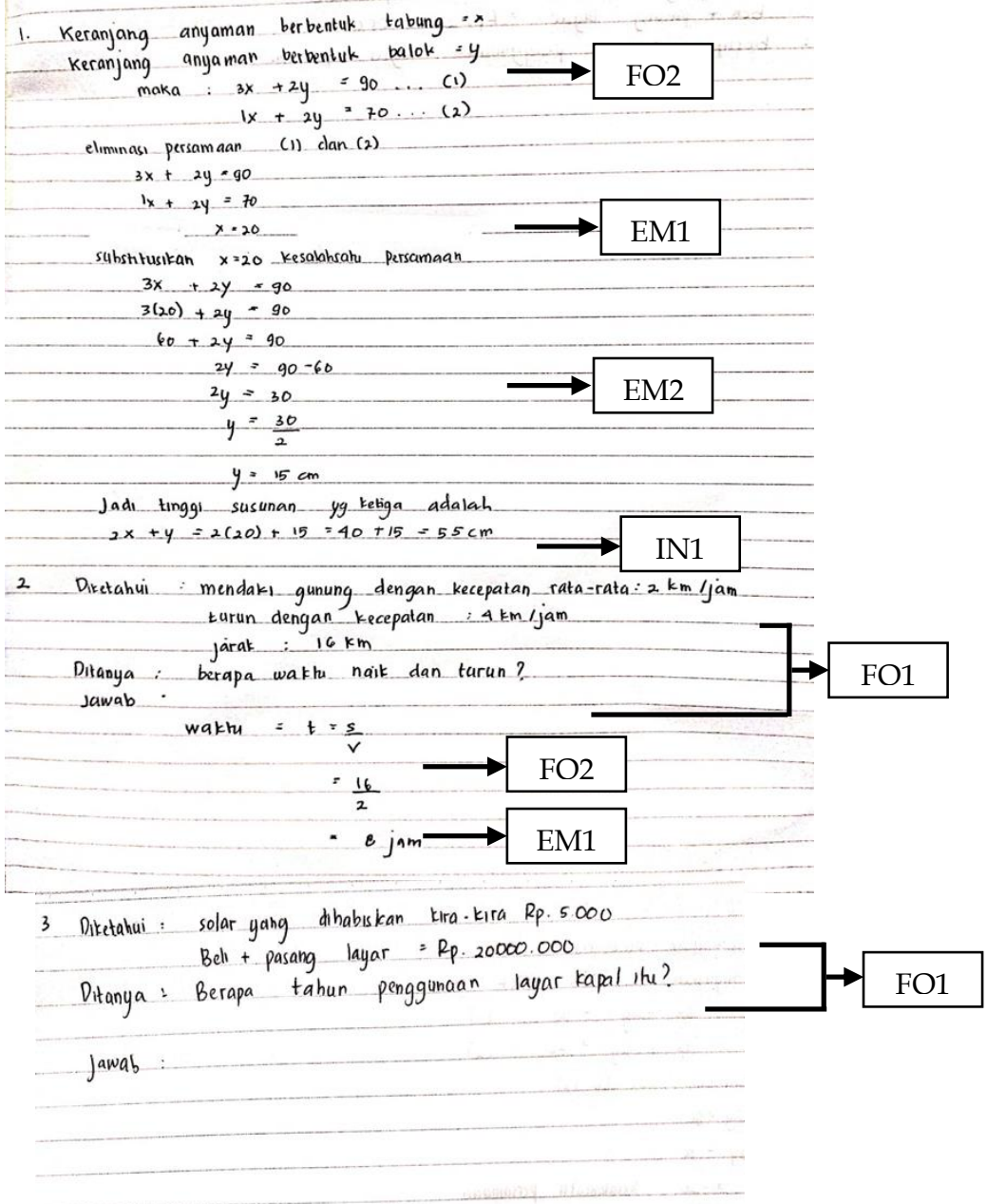

Figure 4. SR Mathematics Literacy Test Answers

In the process of formulating, with indicators identifying aspects of mathematics and 
identifying variables in the problem (FO1), on mathematical literacy problems level 4, namely in the first answer, even though SR did not write important information that was known and did not write down what was asked. When being interviewed, SR can state what is known and what is being asked exactly. While for level 5 and 6 problems, namely in the second and third answers, SR wrote important information but was not precise and complete, SR wrote what was asked in the question

In converting the problem into suitable mathematical language into variable form (symbol and model) (FO2), for level 4 problems, SR changes the height of the cylinder basket with the variable $\mathrm{x}$ and the height of the cuboids basket with the variable $\mathrm{y}$ and changes the arrangement of each basket into the form of a two-variable linear equation. While for level 5 and 6 questions, based on the results of the SR answer, it cannot change the problem into the appropriate mathematical language into the form of variables (appropriate symbols and models).

In the process of employ with indicators to design and implement strategies to find mathematical solutions (EM1), for problems in level 4, SR applies the concept of a twovariable linear equation system, then performs arithmetic operations to find a solution. For level 5 questions, SR was unable to design and implement strategies to find mathematical solutions appropriately because SR could not determine the appropriate mathematical concept and for level 6 questions, SR could not design and implement strategies because when interviewed SR said she did not understand the meaning of the problem.

In applying mathematical facts, rules, algorithms, and structures to find solutions (EM2), for level 4 problems, SR uses elimination and substitution methods to determine the value of $\mathrm{x}$ or the height of the cylinder basket and $\mathrm{y}$ or the height of the cuboids basket, but SR less thorough when eliminating, so that the value and results obtained for the height of the shortest basket arrangement is not correct. For level 5 and 6 problems, SR cannot apply facts, rules, algorithms, and structures to find a solution.

In the process of interpreting with indicators interpreting the obtained mathematical results (IN1), for the level 4 problem, SR cannot interpret the mathematical results obtained correctly because SR IS not careful in the calculation process. For problems level 5 and 6, SR cannot interpret the mathematical results because SR cannot solve the problems given. Further explanation related to the mathematical literacy carried out by SS which is not found in the test results, can be seen in the results of the interview below. 
$\mathrm{P} \quad$ : For question number two, what strategy did you do to find a solution?

SR : For number two it is to determine the climbing time by dividing distance with speed, but I don't know what to do for the next steps, because I don't konw exactly about the problem, Miss

$\mathrm{P} \quad$ : For problem number three, can you mention the variable or mathematical model will you use to find a solution to the problem?

SR : I don't know Miss, I don't understand about the problem

For further explanation regarding the comparison of mathematical literacy results for levels 4, 5, and 6 subjects with high, average, and low mathematical abilities, it is presented in Table 3 below.

Tabel 3. Mathematical Literacy Result

\begin{tabular}{|c|c|c|c|c|c|c|c|c|c|}
\hline \multirow{4}{*}{$\begin{array}{c}\text { Indica } \\
\text { tor } \\
\text { code }\end{array}$} & \multicolumn{9}{|c|}{ Mathematical Literacy Result } \\
\hline & \multicolumn{3}{|c|}{ ST } & \multicolumn{3}{|c|}{ SS } & \multicolumn{3}{|c|}{ SR } \\
\hline & Level & Level & Level & Level & Level & Level & Level & Level & Level \\
\hline & 4 & 5 & 6 & 4 & 5 & 6 & 4 & 5 & 6 \\
\hline FO1 & Complete & Complete & Incomplete & Complete & Complete & Incomplete & Complete & Incomplete & Incomplete \\
\hline $\mathrm{FO} 2$ & Accurate & Accurate & Inaccurate & Accurate & Accurate & Inaccurate & Accurate & Inaccurate & Inaccurate \\
\hline EM1 & Accurate & Accurate & Inaccurate & Accurate & Accurate & Inaccurate & Accurate & Inaccurate & Inaccurate \\
\hline EM2 & Accurate & Accurate & Inaccurate & Inaccurate & Accurate & Inaccurate & Inaccurate & Inaccurate & Inaccurate \\
\hline IN1 & Accurate & Accurate & Inaccurate & Inaccurate & Inaccurate & Inaccurate & Inaccurate & Inaccurate & Inaccurate \\
\hline
\end{tabular}

Based on the mathematical literacy result in Table 3, it reveals that the mathematical literacy of student with high mathematical ability can be broken down as follow: She can write down important information that is known completely, she can determine what is being asked in the questions appropriately, convert the problem into suitable mathematical language into variable form, design and implement strategies to find mathematical solutions appropriately, and can apply algorithms or steps of completion appropriately. By research conducted by Putra and Vebrian (2019), that students with high mathematical abilities in solving PISA problem using Cual Bangka Belitung fabric context show that students with high mathematical abilities can to answer questions correctly, can use argumentation and reasoning to answer questions, make strategy and perform proper arithmetic operations. This is in line with the research conducted by Santoso and Setyaningsih (2020) which found out that subjects with high mathematical ability can write down what is known and asked in the questions completely and correctly, can understand the variables used, can provide examples using variables with other letters, and take steps to answer the problem coherently and correctly.

For the mathematical literacy of students with average mathematical ability, the results of the answers to the mathematics literacy tests and interviews show that students with average mathematical abilities can write down known information, can determine what is being asked, can change the problem into appropriate mathematical language into variables, 
be able to design and implement strategies but are not careful in implementing algorithms or settlement steps so that the resulting solutions are not correct, and cannot make conclusions. By research conducted by Gustiningsi (2015) that students with average mathematical abilities are working on enrichment problems using the PISA model using the South Sumatra context can design strategies to solve problems, use language skills and symbolic operations, but cannot in estimating so that answers and conclusions that obtained is incorrect. This is in line with the research conducted by Santoso and Setyaningsih (2020) which states that subjects with average mathematical abilities can write down things that are known and asked correctly, understand in determining the variables used, can take steps to solve problems even though they are not complete, but cannot conclude.

While, for the mathematical literacy of students with low mathematical ability, it shows that students are not careful in implementing algorithms or steps for completion, cannot design and implement strategies to determine completion, and cannot make conclusions. According to the research that conducted by Putra and Vebrian (2019) that students with low mathematical abilities in solving PISA problem using Cual Bangka Belitung fabric context are less precise in implementing the settlement strategy, are unable to use reasoning and argumentation skills in solving problems. This is in line with research conducted by Khoirudin, Setyawati, and Nursyahida (2017) that subjects with low mathematical skills cannot solve problems correctly, cannot make assumptions and conclusions.

In research conducted by Kafifah Sugiarti, and Oktavianingtyas (2018) stated that students with high and average mathematical ability were able to achieve level 4 mathematical literacy problems. This is in line with research conducted by Charmila, Zulkardi, and Darmawijoyo (2016), that students with high mathematical abilities can solve PISA problems equivalent to level 4 using Jambi culture context. While in this research students with high mathematical ability could not only answer questions for level 4 mathematical literacy but also can answer for mathematical literacy questions for level 5, students with high mathematical ability can answer the questions completely and correctly, while students with average mathematical ability can answer level 4 questions but are not correct in the completion steps and make conclusions.

\section{CONCLUSION AND SUGGESTION}

Based on the discussion and findings in this research, it can be concluded that student with high mathematical ability in solving PISA problems using Indonesian cultural context, 
student capable in (1) formulating, or in identifying mathematical aspects and variables in the problem, converting problems into suitable mathematical language into variables (symbols and models), (2) employing, that are in designing and implementing strategies to find mathematical solutions, applying mathematical facts, rules, algorithms, and structures in finding solutions, (3) interpreting the mathematical results obtained. While, students with average mathematics ability only able to identify mathematical aspects and variables in the problem, convert problems into suitable mathematical language into variables (symbols and models), design and implement solution strategies. For a student with low mathematics ability, the student only able to identify mathematical aspects and variables in the problem, convert problems into suitable mathematical language into variables (symbols and models), design and implement solution strategies for one problem, however for other problems students cannot carry out all the processes in mathematical literacy.

Therefore, it is suggested that for students with average and low mathematical abilities, the teacher can provide training or exercises to solve problems related to mathematical literacy. The teacher may use the context that exists in student life so that students can apply mathematical concepts to solve problems that exist in their daily life. Finally, for students with high mathematical abilities, the teacher can provide enrichment by giving literacy problems to students with a higher difficulty level such as level 5 and level 6 literacy problems so that the students can improve their literacy skills.

\section{REFERENCES}

Akyüz, G. (2014). PISA 2003 Sonuçlarına göre Öğrenci ve Sınıf Özelliklerinin Matematik Okuryazarlığına ve Problem Çözme Becerilerine Etkisi. İlköğretim Online, 9(2), 668-678. https://doi.org/10.17051/io.74461.

Anggoro, A. Y., Julie, H., Sanjaya, F., Andy Rudhito, M., \& Wiadnyana, D. P. (2019). The mathematics education department students' ability in mathematical literacy for the change and relationship problems on the PISA adaptation test. Journal of Physics: Conference Series, 1397(1), 0-6. https://doi.org/10.1088/1742-6596/1397/1/012085.

Bartolini, M. G. (2014). Encyclopedia of mathematics education. In Encyclopedia of mathematics education. https://doi.org/10.1007/978-94-007-4978-8.

Charmila, N., Zulkardi, \& Darmawijoyo. (2016). Pengembangan soal matematika model PISA menggunakan konteks Jambi. Jurnal Penelitian dan Evaluasi Pendidikan, 20(2), 198207.

Gustiningsi, T. (2015). Pengembangan soal pengayaan model PISA level 4 kelas VII SMP. Jurnal Pendidikan Matematika JPM RAFA, 2(2), 198-213. http://jurnal.radenfatah.ac.id/index.php/jpmrafa/article/view/1248.

Jalil, A. 2018. Matematika dalam perspektif sosial budaya. Prosiding SNMPMAT. Vol 1. 
Janah, S. R., Suyitno, H., \& Rosyida, I. (2019). Pentingnya literasi matematika dan berpikir kritis matematis dalam menghadapi abad ke-21. PRISMA, Prosiding Seminar Nasional Matematika, 905-910. https://journal.unnes.ac.id/sju/index.php/prisma/article/download/29305/12924.

Kafifah, A., Sugiarti, T., \& Oktavianingtyas, E. (2018). Pelevelan kemampuan literasi matematika siswa berdasarkan kemampuan matematika dalam menyelesaikan soal PISA konten change and relationship. Jurnal Matematika dan Pendidikan Matematika, 9(3). http://jurnal.unej.ac.id/index.php/kadikma/article/view/10918.

Karmila. (2018). Deskripsi kemampuan literasi matematis siswa ditinjau dari gender. Pedagogy, 3(1), 126-137.

Kementerian Pendidikan dan Kebudayaan. (2017). Literasi adalah kompetensi abad 21. http://pgdikdas.kemdikbud.go.id /literasi-adalah-kompetensi-abad-xxi.

Khoirudin, A., Setyawati, R. D., \& Nursyahida, F. (2017). Profil kemampuan literasi matematika siswa berkemampuan matematis rendah dalam menyelesaikan soal berbentuk PISA. AKSIOMA, 8(2), 33-42. https://doi.org/10.26877/aks.v8i2.1839.

Koshy, V., Ernest, P., \& Casey, R. (2009). Mathematically gifted and talented learners: Theory and practice. International Journal of Mathematical Education in Science and Technology, 40(2), 213-228. https://doi.org/10.1080/00207390802566907.

Lailiyah, S. (2017). Mathematical literacy skills of students' in term of gender differences, AIP Conference Proceedings, 1868(1), 050019-112, https://doi.org/10.1063/1.4995146.

Mahdiansyah, \& Rahmawati. (2014). Literasi matematika siswa pendidikan menengah: Analisis menggunakan desain tes internasional dengan konteks Indonesia. Jurnal Pendidikan dan Kebudayaan, 20(4), 452-469.

Meiliyah, A dan Setianingsih, R. 2019. Profil Komunikasi Matematis Tulis Siswa SMP dalam Memecahkan Masalah Matematika Ditinjau dari Perbedaan Kemampuan Matematika. Jurnal UNES A. 21, 318-327.

Mena, A. B., Lukito, A., \& Siswono, T. Y. E. (2016). Literasi matematis siswa SMP dalam menyelesaikan masalah kontekstual ditinjau dari adversity quotient (AQ). Jurnal Matematika Kreatif-Inovatif, 7(2), 187-198.

Miles, M.B., Huberman, A.M., Saldana, J. (2014). Qualitative data analysis: A. methods sourcebook and the coding manual for qualitative researchers. Thousand Oaks. CA: SAGE, 381.

OECD. (2017). "PISA 2015 assesment and analytical framework: Science, reading, mathematic, financial literacy and collaborative problem solving, revised edition. PISA. Paris: OECD Publishing. http://dx.doi.org/10.1787/9789264281820-en.

OECD. (2018). What 15-year-old students in Indonesia know and can do. Programme for International Student Assessment (PISA) Result from PISA 2018, 1-10. http://www.oecd.org/pisa/ Data

Ojose, B. (2011). Mathematics literacy: Are we able to put the mathematics we learn into everyday use? Journal of Mathematics Education, 4(1), 89-100.

Permendikbud. (2014). Permendikbud nomor 104 tahun 2014 tentang penilaian hasil belajar oleh pendidik pada pendidikan dasar dan pendidikan menengah. Kementerian Pendidikan 
dan Kebudayaan RI, 1-8. https://luk.staff.ugm.ac.id/atur/bsnp/Permendikbud1042014PenilaianHasilBelajar.pdf.

Permendikbud No. 64. (2013). Permendikbud-Nomor-64-tabun-2013-ttg-SI. 2011.

Putra, Y.Y \& Vebrian, R. (2019). Pengembangan soal matematika model PISA konteks kain cual Bangka Belitung. Jurnal Cendekia, 3(1), 1-44. https://doi.org/10.35974/ipd.v3i1.2230.

Santoso, R. M., \& Setyaningsih, N. (2020). Literasi matematika siswa dalam menyelesaikan soal HOTS bentuk aljabar berdasarkan kemampuan matematika. Konferensi Nasional Penelitian Matematika dan Pembelajarannya (KNPMP) V, 62-71.

Stacey, K. (2011). The PISA view of mathematical literacy in Indonesia. Journal on Mathematics Education, 2(2), 95-126. https://doi.org/10.22342/ime.2.2.746.95-126.

Ulfa, M., Lubab, A., \& Arrifadah, Y. (2017). Melatih Literasi Matematis Siswa dengan Metode Naive Geometry. JRPM (Jurnal Review Pembelajaran Matematika), 2(1), 81-92. https://doi.org/10.15642/jrpm.2017.2.1.81-92.

Wahyuni, A., \& Pertiwi, S. (2017). Etnomatematika dalam ragam hias melayu. Math Didactic: Jurnal Pendidikan Matematika, 3(2), 113-118. https://doi.org/10.33654/math.v3i2.61.

Wulandari, E., \& Azka, R. (2018). Menyambut PISA 2018: Pengembangan literasi matematika untuk mendukung kecakapan abad 21. de-Fermat: Jurnal Pendidikan Matematika, 1(1), 31-38. 